\title{
St. George in Legend and Verse
}

\author{
Jacob William LeMaster \\ University of Florida
}

Faculty mentor: Florin Curta, Department of History

\begin{abstract}
This paper investigates the emergence of the cultus of a medieval saint, St. George of Cappadocia, and correlates the production of legend with variations of the saint's passio. It then considers the form of relics in relation to the narrative of their translationes. This is accomplished by examining the political context in which they were translated by Archbishop Hatto of Mainz and the Holy Roman Emperor. It concludes with an exploration of the variations on George's cultus on the Reichenau monastic center and presents an updated English translation of the late ninth or tenth century Georgslied.
\end{abstract}

Keywords: St. George, Reichenau, Hatto I, Georgslied, cult of the saints, relics

\section{The Emergence of the Cultus and its Liturgical Foundations}

In the earliest written accounts of the life and salvific death of St. George of Cappadocia, he was not yet known as a dragon-slayer nor, as he would be more immediately known, as a military hero. Franciscan friar and leading figure of the Bollandists Francis Delehaye described the legends and stories attributed to him as a "sort of Monte Testaccio" - that is, like a mound compiled from broken shards of ancient pottery (Walker, 2003, p. 111). According to Karl Krumbacher (1911), each one of the five variants of George's passiones known (and probably produced) in the sixth century mention his soldiering, but the focus in these texts is on the physical suffering involved in his martyrdom. Large-scale veneration of the saint by localized clusters of the faithful emerged early, and the earliest evidence of the cultus can be found in in the Greek-speaking eastern edge of the Roman Empire, centered around his tomb in Lydda (Diospolis). The cult spread westward at an early date with surprising speed (Ewig, 1964). The earliest miracles performed by George already involved some of his military powers. For example, in Palestine: he appeared in a vision as a mounted soldier on horseback, and then in an image he is represented in full armor as the protector of his shrine against violation by a band of Arab warriors, which he miraculously repels (White, 2013). 
In the mid-sixth century there was already a church dedicated to George in Mainz. It is mentioned by Venantius Fortunatus who praised George as a saint "cuius in hunc mundum spargitur altus honor," while maintaining that even as far from his tomb in Lydda as Mainz, George could offer pilgrims his defensive powers: "Qui uirtute potens orientis in axe sepultus / ecce sub occiduo cardine praebet opem" (Maskarinec, 2018, pp. 185, 253). By the seventh century, George had joined the état major of saints, alongside Theodore Stratilates, Theodore Tiron, Demetrius, Procopius, and Mercurius. George was called "unconquerable shield of the soldiers of Christ," as well as, "George, the ally of the [Roman] emperor" (White, 2013, p. 23). The military overtones of his sainthood, as reflected in the passions matched the preoccupation of the centralized imperial cult of military saints. As such, variations of the passio moved quickly from Constantinople through Rome into the periphery of Christendom, a process beginning at least by the eighth century. The earliest institutions in Western Europe which were named after George, and which venerated the saint, were the 'Byzantine' military fortifications in Italy. In other words, these are the first testimony of the 'western' style of militarization of the primarily Greek saint. The first text in Italy extant about George is a sixth-century inscription on the Portia Appia, which has been dated to before or immediately after the Gothic Wars, and was most likely put up by a soldier (Maskarinec, 2015). In the eighth century, it becomes possible to describe whole "families" of geographically distributed variations of St. George's passio. It is not surprising given this popularity that the early accounts of George's miracle-working in the genre of the gesta sanctorum martyrum de Sancti Georgii (alongside the officially recognized proconsular Acts of the Martyr) were subject to a great deal of literary scrutiny by the learned theologians of the seventh to ninth centuries. One of the hands responsible for Decretum Gelasianum de Libris recipendis et non recipendis (the list of canonically permissible texts as nominally compiled by the order of Pope Gelasius I in the first half of the sixth century) advises the reader to be wary of accounts "[written] by infidels and idiots," and goes on to criticize the popular passion of St. George as just such an example of legend creeping into the territory of hagiographic history (Döbschutz, 1912, pp. 39-42).

In order to demonstrate the trajectories of George's cultus north of the Alps, two vital pieces of evidence must be considered. The first of these examines the narrative and structural composition of George's passio and a surprising discovery made by Pope Zacharias (r. 741-752). This will further lead to a discussion on the calendrical legenda. 


\section{St. George's Passio and Relics}

The format of the story as it circulated is straightforward and follows a basic framework: George, usually (although not always) associated with a military or governmental functionary position, defies his earthly lord in favor of martyrdom. The conversion narrative also usually includes George's successful proselytization of Queen Alexandra and many others, ending with his harsh punishment at the order of an imperial authority resulting in his death, resurrection, and heroic displays of miracles. While this format is ubiquitous, geographic, political, and linguistic borders create differences. In the earliest Greek variations of the passion (such as Pasikrates, $\mathrm{X}^{1}$ ), we find George's martyrdom emphasized and his miracles only follow his death (Haubrichs, 1979). Further division can be explicated: one group of texts $\left(X_{l a t}\right)$ shifts the emphasis to the otherworldly power wielded by George on Earth; still other texts (Y) originated in Rome. Of these $\mathrm{Y}$ group texts, there are two major categories: $\mathrm{Y}^{1}$ is long-form and is fully invested in the fantastical elements of George's miracles, while $\mathrm{Y}^{2}$ is shortened, and found throughout the Frankish lands. A different group of texts ( $\mathrm{Z}$ recension) is perhaps earlier than any of the above and may have entered Gaul directly sometime in the sixth century. In one of these variant accounts, he is able to call upon heavenly fire to immolate the emperor and his entire court before his death and resurrection (Maskarinec, 2018). In the Georgslied, he "really was resurrected there, he rose from the dead, and at once began to preach wonders."

Every year following the ca. 745 discovery of George's relics beneath the Lateran, on the Thursday following Ash Wednesday, the pope would make an official visit and perform mass at George's diaconia (a form of late antique hospital stemming from the Roman grain dole) at Velabro (Maskarinec, 2018). For Romans, and especially for those visiting S. Giorgio al Velabro, the miraculous discovery of George's "most holy head, stowed in a casket, in which he [Pope Zacharias (r. 741-752)] also found a note made out in Greek letters," shifted the center of gravity for the veneration of George away from Constantinople (Davis, 2007, p. 47). Whether the veneration of the saint in the east was affected by events in Rome or by imperial policies in favor of iconoclasm, the Greek saint now took on a new "life" in the Latinate west. The feast commemorating the salvific death of the Cappadocian martyr was often listed as being celebrated on one of three dates: April 23, 24, or 25. It was typically located on liturgical calendar entries for April 23 in the Roman tradition of the Hadrianum, while April 24 or 25 were commemorated in many popular martyrologies, which may have been viewed as increasingly 
inferior by the educated elite of the late Carolingian literati. Notker 'Balbulus', a late ninth century monk at St. Gall (located approx. 45 miles from Reichenau), included in his own martyrology two feast dates for George. He notes for April 25:

His passion is celebrated among the Romans and nearly all others on the 9th day before the Kalends of May (April 23)... On that account, I thought this should be pointed out so that our patriarch Hatto of Mainz might act cautiously in fixing his feast day, that is, of St. George. (Maskarinec, 2016, p. 150)

This hagiographical discourse from the late ninth century is centered on reaction to the affinities of particular traditions. When these conflicted with the project of universalization undertaken by clerical elite they were immediately noticed by contemporary hagiographers. In order to trace more directly the conditions in which the Georgslied was produced, a brief sketch of political history leading up to the time in which it was written becomes necessary.

\section{The Carolinigian Decline}

On January 13, 888, the last Carolingian Kaiser to lay claim to all the territories of Charles the Great's empire died: “On [Charles III's] death the kingdoms he had ruled over, deprived of a legitimate heir, separated out from the body of his empire and each, instead of waiting for its natural lord, chose a king from its own bowels. This was the cause of great wars" (Regino, trans. MacLean, 2009, p. 129). Preceding this, the Carolingian $d u x$ of Carinthia (a title of military origins that is falsely cognate with the modern English 'duke') led a force of "Bavarians and Slavs" against him (Reuter, 1994, p. 112). Some historians have maintained that like the Merovingians of Late Antiquity, Arnulf simply "began ruling” (Reuter, 1991, pp. 119-121). The final royal charter (diplomata) issued by Charles III was sealed on November 17, 887 and Arnulf's first royal document was signed on November 27 of the same year.

The new king of the eastern Franks, Arnulf 'of Carinthia' was immediately tasked in navigating very delicate and decidedly hostile political waters where great families challenged the legitimacy of his holy blood (Klaniczay, 2002). Failing to obtain by consensus the prestige necessary to enforce his claims to the whole of the Carolingian Empire, Arnulf began a series of military campaigns to centralize his power bases and extend his territorial authority against the rise of the powerful reguli. A new mode of the old court as based in Lotharingia gave way to one in which both individual regions (primarily the Carolingian comital provinces and ascendant 
stem-duchies) and ecclesiastical jurisdictions began to exercise unique influences over specific aspects of imperial practices. Within Arnulf's core demesne (lands directly held and over which Arnulf exercised full legal authority and right of personal possession), he was mostly held in high esteem, but he had some difficulty fully wielding imperial authority. The main problems arose in what had been the primary holdings of Charles III, i.e. Swabia. In 887, as part of the negotiations for his abdication, Charles III had entrusted as hostage his illegitimate son Bernard to Arnulf. By 890, Bernard became a figurehead in a rebellion against him based in Swabia and Swabian Alsace, in which participated the count of the Linz- and Argengau along with the abbot of St. Gallen. Among Arnulf's allies in this Swabian affair were two very important players, both bishops with holdings on Lake Constance: Hatto, the abbot of Reichenau and the former chaplain of Charles III who would in the course of events become archbishop of Mainz, and Salomon, the archbishop of Konstanz. The facts of the 'civil war' are mostly evidenced by reconstructed charters, and the annals do not speak directly of the rebellion (Reuter, 1994, p. 118-120). Only after Bernard's death in 891 were political interests in the region re-aligned with Arnulf's court, allowing his attentions to turn to the problem of Scandinavian raiders in the northern reaches of his newly acquired territories.

On the periphery of Arnulf's Empire, renewed Viking attacks followed the 878 peace accords of the heathen raiders with Ælfred of Wessex. In 891, before the victory of Arnulf's forces at the River Dyle in the same year, the Viking forces were met by Sunderolt, the archbishop of Mainz. He was struck down as a consequence of "attacking them rashly" (Reuter, 1994, p. 121). Although the precise date remains unknown, the Annals of Fulda report that Hatto, the abbot of Reichenau, was appointed archbishop following Sunderolt's death. In the 891 entry, he was described as "a man of subtle mind" (Reuter, 1994, p. 121). Complex political interests emanated from Rome and drew Arnulf to return in 896; this time with a destination of the eternal city, where he was crowned emperor by his former enemy, Pope Formosus, in late February of the same year. Again accompanying the military train of the emperor was Hatto, now one of Arnulf's most powerful allies. On arriving at the Lateran, Hatto was invested with the relics which Zacharias had miraculously found hidden deeply in the ancient catacombs over a century prior. While contemporary eyewitness accounts of what must have been a highly ceremonial translatio have been lost to time, today, the relic is still housed in St. Georg Abbey on Reichenau-Oberzell. As Notker explained in the Martyrlogium: "[Hatto] brought to Alemannia, 
to his new monastery [St. Georg in Reichenau-Oberzell], his [St. George's] head and a certain other limb with many other great relics of saints, all granted to him by Pope Formosus" (Maskarinec, 2016, p. 150). It was to a "new monastery" that Hatto had the honor of translating St. George's relics. The construction of the abbey honoring St. George almost certainly predated the acquisition of the relics, and their arrival ca. 900 seems to have encouraged a new phase of construction (Zettler, 1989). It was in this context that evidence was discovered of the original reliquary, which may have been an ornmanetal box carved in stone with a dome-shaped lid. The sacremental windows looking over the alternatively named Sepulcrum or Loculus were in use until the 1308 high altar was constructed and the relics redeposited (Zettler, 1989, p. 104). Recent scholarship has demonstrated that that this site was the most important center for the cultus in the Swabian context (Zettler, 1989).

\section{Reconstructing Georgslied : A New English Translation for the Twenty-First Century}

One of the literary practices related to George's cultus survives in lyrical form: the Georgslied $(G L)$, an Old High German hymn to St. George. The hymn is extant in its vernacular, monumental form in only one manuscript. On the basis of paleographic features, the text was dated to the early or mid-tenth century, and its hagiographic content resembles and provokes to memory an older, oral tradition (Haubrichs, 1979). This text, and the larger religious movement it represents (Reliquienkult) begs questions of the locality (space and place) in which it was composed. To highlight this, the focus of my research has centered around a new translation of the text of the hymn to St. George found in the last pages of Otfrid's Evangelienbuch; the Codex. Pal. Lat. 52 manuscript was composed in Germanic vernacular.

While Haubrichs (1979) convincingly attempted to demonstrate that the author of $G L$ represented an outgrowth of the Franconian Georgskult in the vicinity of Prüm, local traditions alongside an only recently overturned trend in the history of literary scholarship of Georgslied have claimed its Alemannic (Swabian) provenance, often associating the text with the monastic community on the Reichenau. The idea of $G L$ as an Alemannic invention in celebration of the translatio of George's relics to the new abbey in his honor at Reichenau-Oberzell was firmly cauterized from social memory into history by K. Siemers in 1939 (Voorwinden, 1992). Although initially adopting this view of the text, the tradition of an Alemannic author was proved to be in linguistic error by Helmut de Boor (1954). Rather than discarding all notions of 
connection to the oral tradition, GL embodies the form and function of the cult to St. George as developed at the Reichenau over the ninth and tenth centuries (Haubrichs, 1993).

If we cannot locate the scribe geographically, can we name him? Authorship of GL remains a controversial and intricate debate within historical hagiography. Throughout the nineteenth century, many conjectured that the notation following the text in the manuscript, nequeo Vuisolf ("I cannot [continue], Vuisolf") represented the name of the copyist who originally gave up in his attempts to transcribe the hymn from some lost source to its extant written vernacular form. The manuscript as available through the Universitätsbibliothek Heidelberg digital library does not retain a legible 'nequeo' notation, though the marking that may read Vuisolf is faintly visible, set clearly down and away from the final portion of text. Despite the existence of the notation having inspired some to mistakenly identify the author, the signing of texts was not a common practice amongst the almost wholly anonymous copyists in the area in which the hymn was composed, and as Haubrichs (1979) has proved conclusively, the name is not related to the author of the $G L$.

From here, we must examine alternative theories of origin for the text. In the "little book for the travelling Frenchmen" also known as the Paris Glosses, the author makes use of phonemic parallels between his native tongue and a foreign language. In the same way, it has been suggested in recent scholarship that $G L$ was penned by a non-German speaker, using either Greek or German source material and that the author may have also been a Greek layman working within an Ottonian monastic community (Voorwinden, 1992). Strong ties between the Ottonian and Byzantine monarchs were forged in the late tenth century, culminating in the marriage of Otto II with Theophanu in 972 (Davids, 1995). Because of such strong implications, a critical attitude is to be stressed when considering the potential political and chronological environments in which to place the authorship of the text (Haubrichs, 1995). As concluded by Voorwinden (1992) and contrary to Matzke (1903) and Haubrichs' (1995) determinations, there is not presently a consensus determining standardization. I have attempted throughout the piece to favor clarity of the content over a more literal glossing; the core thematic drive of the lied is thus preserved:

George travelled with a great host to the place of judgement; From his own march he came, with many people; He went to the thing at the court of his sovereign; This judgement day would 
be infamous; George became dear to God; He lost the kingdom of the world, but won the kingdom of Heaven; He did this thing himself, the mark graf George.

At the royal court, where all the vassals had gathered, the petty kings spoke to him; They wanted to seduce George, but he would not hear them. Steadfast was George's spirit and mind; I assure you, he would not hear them. Therefore, he did all this through God, and he praised God for it, That he did himself, St. George. Then he was sentenced to imprisonment immediately [by the court].

[But] there were marvelous angels flying with him. He found two women, and offered them salvation, At this place he wrought a wonder; [he prepared] food [of holy wisdom.] George wrought this miracle there, it is true. George pleaded [in prayer] and to him the lord granted everything. The Lord granted all to George that he asked of him. He made the mute to speak, the deaf to hear, The blind to see, the lame to walk.

For many years, a wooden stump stood here: but then suddenly new foliage sprung out of it, George wrought this miracle there, it is true. The tyrannical leader became angry, [Tacianus] became scornful of his wonders: He said that George was a sorcerer. He ordered George to be captured, that he was to be stretched out, And hit firmly with a wonderfully sharp sword. I know it's true, that George really was resurrected there. George rose from the dead, and at once began to preach wonders. George showed the heathens their sin.

And the despot grew increasingly furious, He ordered George to be tied up and bound on a wheel. I tell you the truth, they broke him into ten pieces. I know it's true, that George really was resurrected there. George rose from the dead, and at once began to preach wonders. George showed the heathens their sin. They flailed him hard with the whip, and ordered him to be crushed and burned to ashes.

He was thrown into a well; he was a son of God. They rolled a large and heavy stone onto it, And they began to walk around him, demanding George to resurrect, George seemed as magnificent there as the wonders he performed, I know it's true, that George really was resurrected there. George rose from the dead, and at once began to preach. George shamed the heathen men. He brought the dead to life.

[...(George) asked him (a dead man whom George has resurrected) to rush to him, He ordered that he speak - he said: Jobel is my name, simply believe it. He said that he (and his dead comrade) had been damned, betrayed by the devil...] 
In George's own voice this was announced. Then he went to the Queen's room, He began to teach her, and she began to hear his teachings. Elessandria, she was virtuous. She hurried to do good, and to donate her dowry, She gave away her wealth; It was enough for many years of healing. From eternity to eternity, she is in grace...

The appeal was made in St. George's own voice. When George raised his hand, Apollo shivered. He commanded the hounds of hell, when he drove them immediately into the underworld.

[I cannot continue, (V)Vuisolf. $]^{1}$

\section{Conclusions}

Memory of the early Middle Ages is marked by the continuation of social, political, religious, and economic reorganization throughout the Latinate West in the wake of the slow collapse and reapproporiation of Roman centralized power. Although it has long been perceived as an era of stagnation by those who write off the period as a 'Dark Age', these supposedly darkened times witnessed some of the most important develoments in the history of power and faith in the medieval period. The traces of the past inherent in the relics of saints are at once physical and spiritual. From a literary perspective, the adoration of the sacred dead represented by the writing of the lives of the saints provides a seemingly unique window for understanding cultural models of literature and the categorizations of knowledge. Regardless of when it was set to parchment, the source material (as a combination of orality and written materials) on which $G L$ 's author depended drew from an extensive and mobile tradition with vital monastic, ecclesiastic, as well as private roots, set foundationally in the late ninth century Carolingian decline. I have shown that there exists within the variations in form of St. George's passion a general sense of four major groupings, of which $G L$, found almost surreptitiously inserted at the end of a copy of Otfrid of Weißenburg's ninth-century Evangelienbuch, can be cautiously classified as a combination of typographic forms stemming from the $\mathrm{X}_{\text {lat }}$, tradition. The text of $G L$ itself demonstrates movement toward a clear break with Latinate topographic trends, not only linguistically, but also in the ways miracles and ordeals are portrayed narratively, which may lend support to Voorwinden's Greek scribe hypothesis. With respect to political developments, St. George's cult was to be found at the center of the processes of transformation of imperial 
power in the late Carolingian period. A restoration of centralized authority associated with Henry the Fowler as precursor to the Ottonian 'Renaissance' (blütezeit) would soon come to dominate the long tenth century, in which St. George's elevation to the status of venerated saint in the new imperial household demonstrated both the legacy and continuity of the practice of St. George's cult as it was cultured by Archbishop Hatto on the Reichenau monastic complex.

\section{Acknowledgements}

I would like to dedicate this paper to my late Oma (grandmother) Hildegarde Burger Huggins, without whom I would never have explored the tenth century historical foundations of the Georgskult as it developed into the eleventh-century monastic settlement Skt. Georgen im Schwarzwald (presently Schwarzwald-Baar county), where over nine hundred years later, she would be born. What started as inquiry into how a place got its name became something much larger and eventually resulted in this project, and for this I must extend my sincerest gratitude to Dr. Florin Curta for sparking a passion in me for medieval history. In this endeavor I have had the full support of both the History Honors Program and Medieval \& Early Modern Studies faculty, and I must also thank Dr. Will Hasty for the many hours spent going line-by-line in translation of the Old High German texts. Dr. Mary Watt provided assistance in navigating the discourse on the commodification of sacred texts and images, and I would like to thank her for both her expertise and personal kindness. In this vein I would also like to thank Dr. Jules Gliesch and many others for having been subjected to reviewing my translation work for publication. Finally, my family has provided unending emotional support throughout this process, and I would like to especially thank Helen, Wilene, and Thomas "TJ" for their patience as I continue my education; a process in which my late father, William "Bill" was instrumental.

\section{References}

. (n.d.) MS Codex Palatini Germanici lat. 52. 200v-201v. Universitätsbibliothek Heidelberg. Retrieved from https://digi.ub.uni-heidelberg.de/diglit/cpl52/0438.

Davids, A. (1995). The Empress Theophano: Byzantium and the West at the Turn of the First Millenium. Cambridge: Cambridge University Press.

Delehaye, H. (1962). The Legends of the Saints. (D. Attwater, Trans.). New York, NY: Fordham University Press.

Dobschütz, E. (1912) Das Decretum Gelasianum De Libris Recipiendis Et Non Recipiendis. Leipzig: J.C. Hinrichs.

Droysen, J.G., Andrew, E.B., Krüger, H., \& Buckle, H.T. (1893). Outline of the Principles of History (Grundriss der Historik). Boston: Ginn \& Company.

Duchesne. (Ed.). (2007) The Lives of the Eighth-Century Popes. (Davis, Trans.). Liverpool: Liverpool University Press.

Ewig, E. (1964). Die Verehrung orientalischer Heiliger im spätrömischen Gallien und im Merowingerreich. Festschrift Percy Ernst Schramm Zu Seinem Siebzigsten Geburtstag Von Schülern Und Freunden Zugeeignet, 1, 385-400. 
Fuhrmann, H. (1970). Der angebliche Brief des Erzbischofs Hatto von Mainz an Papst Johannes IX. Mitteilungen des Instituts für Österreichische Geschichtsforschung, 78, 51-62.

Haubrichs, W. (1979). Georgslied und Georgslegende: Text und Rekonstruktion. Konigstein/Ts.: Scriptor.

Haubrichs, W. (1993). St. Georg auf der frühmittelalterlichen Reichenau. Hagiographie, Hymnographie, Liturgie, und Reliquienkult. Herrschaft, Kirche, Kultur. Beiträge zur Geschichte des Mittelalters. Festschrift für Friedrich Prinz zu seinem 65. Geburtstag, Monographien zur Geschichte des Mittelalters 37, 505-537. Stuttgart: Hiersemann.

Haubrichs, W. (1995). Zur Rezeption der Georgslegende und des althochdeutschen Georgsliedes. Deutsche Literatur und Sprache von 1050-1200: Festschrift für Ursula Hennig zum 65. Geburtstag, 71-92.

Klaniczay, G. (2002). Holy Rulers and Blessed Princesses: Dynastic Cults in Medieval Central Europe Cambridge: Cambridge University Press.

Krumbacher, K. (1980). Der Heilige Georg in der griechischen Uberlieferung. München: Universitätsbibliothek München.

Maskarinec, M. (2015). Building Rome Saint by Saint: Sanctity from Abroad at Home in the City (6th-9th Century). (Doctoral dissertation). Retrieved from University of California Open Access Publications database.

Maskarinec, M. (2018). City of Saints: Rebuilding Rome in the Early Middle Ages. Philadelphia: University of Pennsylvania Press.

Matzke, J. (1903). Contributions to the History of the Legend of Saint George, with Special Reference to the Sources of the French, German and Anglo-Saxon Metrical Versions. PMLA 18, 1: 99-171.

Regino and Adalbert. (2009). History and Politics in Late Carolingian and Ottonian Europe: The Chronicle of Regino of Prüm and Adalbert of Magdeburg. S. MacLean. (Ed.). Manchester: Manchester University Press.

Reuter, T. (1991). Germany in the Early Middle Ages, c. 800-1056. London: Longman.

Reuter, T. (Trans.). (1994). The Annals of Fulda. Manchester: Manchester University Press.

Voorwinden, N. (1992). Die bedeutung der Philologie für die Literaturwissenschaft, am Bespiel des althochdeutschen Georgsliedes. Neophilologues, 76, 569-585.

White, M. (2016). Military Saints in Byzantium and Rus, 900-1200. Cambridge: Cambridge University Press.

Wickham, C. (2009). Early Medieval Italy: Central Power and Local Society, 400-1000. Ann Arbor: University of Michigan Press.

Zettler, A. (1989). Die spätkarolingische Krypta von St. Georg in Reichenau-Oberzell. Denkmalpflege in Baden-Württemberg-Nachrichtenblatt der Landesdenkmalpflege, 18(2), 97-105.

\section{Endnotes}


${ }^{1}$ This is an original translation of MS Codex Palatini Germanici lat. 52. 200v-201v. Voorwinden's (1992) simplified transcription, on which it is based, removes all punctuation, reconstructive elements from Haubrichs, and currently unreadable script in places where it has either faded or been otherwise damaged (i.e. multiple lacunae are present). There are two locations set away from the body of the text and bracketed due to their potential for exclusion and other irregularities. 